\title{
Porównanie bayesowskich modeli Copula-AR(1)-GARCH(1,1) z asymetrycznością rozkładów warunkowych*
}

\section{Streszczenie}

Celem artykułu jest formalne porównanie mocy wyjaśniającej dwuwymiarowych bayesowskich modeli Copula-GARCH z warunkowym skośnym oraz symetrycznym rozkładem $t$-Studenta na przykładzie danych pochodzących z polskiego rynku finansowego. Przedmiotem porównania były 22 modele Copula-AR(1)-GARCH(1,1) różniące się kopulą oraz występowaniem skośności rozkładów brzegowych. W kontekście rozważanych modeli opracowane zostały metody Monte Carlo z funkcją ważności w celu uzyskania charakterystyki rozkładów a posteriori oraz wartości brzegowych gęstości macierzy obserwacji. Dla analizowanych danych empirycznych bardziej prawdopodobne a posteriori okazały się modele z symetrycznymi warunkowymi rozkładami $t$-Studenta. Dla logarytmicznych dziennych stóp zwrotu subindeksów indeksu WIG najwyższe prawdopodobieństwo a posteriori uzyskał model z kopulą Claytona-Gumbela. Zastosowanie skośnego rozkładu $t$-Studenta nie poprawiło mocy wyjaśniającej modeli Copula-GARCH.

Justyna Mokrzycka, Uniwersytet Ekonomiczny w Krakowie, Wydział Finansów i Prawa, Katedra Matematyki, ul. Rakowicka 27, 31-510 Kraków, e-mail: justyna.mokrzycka@uek.krakow.pl

* Artykuł powstał w wyniku realizacji projektu badawczego finansowanego ze środków przyznanych Wydziałowi Finansów i Prawa Uniwersytetu Ekonomicznego w Krakowie w ramach dotacji na utrzymanie potencjału badawczego. Autorka serdecznie dziękuje Pani Profesor Annie Pajor za cenne uwagi merytoryczne. 
Słowa kluczowe: kopula, model Copula-AR-GARCH, wnioskowanie bayesowskie, bayesowskie porównanie modeli, technika bayesowskiego łączenia wiedzy, metoda Monte Carlo z funkcją ważności.

Klasyfikacja JEL: C11, C51, C52, C58.

\section{Wprowadzenie}

Modelowanie powiązań i zależności między aktywami finansowymi, z jednoczesnym uwzględnieniem charakterystycznych cech warunkowych rozkładów brzegowych tych aktywów oraz formalnym porównaniem proponowanych struktur zależności, ma istotne znaczenie nie tylko teoretyczne, ale także praktyczne. Prognozowanie zmienności oraz dynamiki zależności pomiędzy procesami jest jednym z podstawowych zagadnień stochastycznego podejścia do wyceny instrumentów pochodnych, optymalizacji portfeli inwestycyjnych i kalkulacji wartości zagrożonej (value at risk). Biorąc pod uwagę zarządzania ryzykiem, uwzględnienie w modelowaniu wielowymiarowej struktury zależności jednoczesnego przyjmowania wartości ekstremalnych może być kluczowe dla podejmowania decyzji. Zastosowanie kopuli w modelowaniu wielowymiarowych rozkładów jest jednym z proponowanych podejść do tego zagadnienia. Rodzina kopul dwuwymiarowych obejmuje kopule o symetrycznych oraz asymetrycznych wartościach tzw. współczynników zależności ogonowych ${ }^{1}$ (tail dependence) [Joe 1993].

Podstawowym narzędziem ekonometrii finansowej, zarówno w analizach jednowymiarowych, jak i wielowymiarowych, jest proces GARCH (Generalised Autoregressive Conditionally Heteroscedastic) zaproponowany przez T. Borellsleva w 1986 r. jako uogólnienie procesu ARCH (Autoregressive Conditionally Heteroscedastic). W wyniku poszukiwań modeli lepiej opisujących dane finansowe powstały różnego typu uogólnienia i modyfikacje podstawowego procesu GARCH; są to w przypadku jednowymiarowym m.in. EGARCH, TGARCH, GJR-GARCH, IGARCH, FIGARCH, a wielowymiarowym m.in. VECH, CCC, DCC, BEKK [Fiszeder 2009]. Model Copula-GARCH zaproponował A.J. Patton [2006b] oraz E. Jondeau i M. Rockinger [2006]. Specyfikacja tego modelu pozwala na ujęcie asymetrii w rozkładach warunkowych oraz asymetrii w strukturze zależności przez dobór odpowiedniej kopuli.

W niniejszym artykule przedmiotem rozważań były dwuwymiarowe bayesowskie modele Copula-AR(1)-GARCH(1,1) z warunkowymi rozkładami brzegowymi $t$-Studenta i skośnymi $t$-Studenta. W modelu Copula-GARCH wielowymiarowy

${ }^{1}$ Prawdopodobieństwa warunkowego przekroczenia kwantyla rzędu $\alpha$ przez jedną zmienną losową, pod warunkiem że uczyni to druga zmienna losowa przy rzędzie kwantyla dążącym do 1 lub 0. 
rozkład wektora losowego definiowany jest z wykorzystaniem warunkowych kopul, które w konsekwencji twierdzenia Sklara, mogą zostać uznane za funkcje określające strukturę zależności pomiędzy składowymi tego wektora. Z kolei warunkowe wartości oczekiwane i wariancje rozkładów brzegowych w modelu opisywane są, odpowiednio, strukturą autoregresyjną i $\operatorname{GARCH}(1,1)$. Istnieje możliwość rozszerzenia przedmiotowych badań na przypadki o wyższych wymiarach. Powodami ograniczenia się do przypadku dwuwymiarowego są względy numeryczne związane z czasem obliczeń wartości brzegowej gęstości macierzy obserwacji (w przypadku wyższych wymiarów jest to bardzo czasochłonne) oraz możliwość rozważania dużej liczby kopuli dwuwymiarowych. Warto również wspomnieć, że wielowymiarowe kopule eliptyczne albo mają zerowe współczynniki zależności ogonowych, albo zależności te są symetryczne, zależne od liczby stopni swobody. Z kolei kopule archimedesowe z uwagi na małą liczbę parametrów nie pozwalają na swobodne sterowanie strukturą zależności [Doman 2011]. Wobec tych mankamentów w wielowymiarowym modelowaniu proponuje się stosowanie kaskad kopuli dwuwymiarowych (pair-copula) [Czado 2010, Doman 2011].

Głównym celem badań było porównanie mocy wyjaśniającej modeli Copula-GARCH ze skośnym i symetrycznym rozkładem $t$-Studenta na przykładzie danych finansowych. Do estymacji i porównania modeli zastosowano podejście bayesowskie, które jest podejściem formalnym i całościowym. Weryfikację konieczności uwzględniania skośności rozkładów jednowymiarowych w przedmiotowym modelu przeprowadzono dla logarytmicznych stóp zwrotu notowań dwóch subindeksów indeksu WIG - WIG-Budownictwo oraz WIG-Informatyka. Charakterystyki próbkowe tych danych wskazują na występowanie asymetrii rozkładów brzegowych. Opracowano również metody Monte Carlo z funkcją ważności w kontekście stosowanych modeli.

Pierwszą pracą z zakresu bayesowskiego porównania modeli jest praca [Huard, Evin i Favre 2006], w której przedstawiono wyniki bayesowskiego porównania wybranych 9 kopul, proponując rozkład a priori bezpośrednio dla współczynnika tau Kendalla. Następnie R. Silva i H.F. Lopes [2008] zastosowali podejście bayesowskie do szacowania parametrów 6 wybranych kopul; porównanie modeli opierało się na kryteriach informacyjnych, m.in.: DIC (deviance information criterion), AIC i BIC. W publikacji [Rossi, Ehlers i Filho 2012] zaprezentowano wyniki porównania 5 modeli Copula-GARCH z warunkowym brzegowym symetrycznym i skośnym rozkładem $t$-Studenta dla danych symulowanych. Porównanie modeli opierało się na kryteriach informacyjnych, m.in.: DIC, EAIC (expected value of the Akaike information criterion) i EBIC (the expected value of the Bayesian information criterion). W pracy [Mokrzycka i Pajor 2016] przedstawiono bayesowskie 
porównanie 11 modeli Copula-AR(1)-GARCH(1,1) z warunkowym brzegowym rozkładem symetrycznym $t$-Studenta dla subindeksu indeksu WIG.

$\mathrm{W}$ artykule przedstawiono wyniki bayesowskiego (opartego na prawdopodobieństwach a posteriori modeli) porównania modeli Copula-GARCH o różnych strukturach zależności oraz dwóch typach warunkowych rozkładów brzegowych z wykorzystaniem danych rzeczywistych. Zaprezentowana w pracy estymacja bayesowskich modeli Copula-GARCH oraz ich porównanie stanowiła kontynuację badań prezentowanych w pracy [Mokrzycka i Pajor 2016]. Przedstawiono bayesowski model Copula-AR(1)-GARCH(1,1), omówiono estymację i porównanie modeli bayesowskich wraz z techniką bayesowskiego łączenia wiedzy oraz krótko zaprezentowano sposób estymacji parametrów modelu z wykorzystaniem metody Monte Carlo z funkcją ważności. Przedstawiono także wyniki empiryczne dla wskazanych powyżej stóp zwrotu z okresu od 1.08.2005 do 21.09.2015. Obliczenia wykonano z użyciem programu MATLAB2014 oraz opracowanych w tym programie autorskich procedur.

\section{Bayesowski model Copula-AR(1)-GARCH(1,1)}

Niech zbiór $Y \times Y_{f} \subset R^{(T+s) \times n}$ jest zbiorem możliwych realizacji badanego zjawiska. Wektor $\left(y, y_{f}\right) \in R^{(T+s) \times n}$ oznacza pojedynczą realizacje tego zjawiska, przy czym $y \in R^{T \times n}$ jest wektorem zaobserwowanych wartości, natomiast $y_{f} \in R^{s \times n}$ wektorem wartości prognozowanych. Badane zjawisko opisane jest przez model statystyczny $\left(Y \times Y_{f}, F, P\right)$, gdzie $F$ jest $\sigma$-agebrą podzbiorów zbioru $Y \times Y_{f} \subset R^{(T+s) \times n}$ ( $\sigma$-algebrą zbiorów borelowskich); $P=\left\{P_{\theta}: \theta \in \Theta\right\}$ parametryczną rodziną rozkładów prawdopodobieństwa określonych na $F$ o funkcjach gęstości $p(\cdot \mid \theta): Y \times Y_{f} \rightarrow R^{+} \cup\{0\}$ określonych na zbiorze możliwych realizacji badanego zjawiska. Następnie niech $p(\theta)$ będzie funkcją gęstości rozkładu wektora parametrów, czyli tzw. rozkładem a priori. Bayesowski model statystyczny jest jednoznacznie określony przez gęstość łącznego rozkładu prawdopodobieństwa wektora zmiennych obserwowalnych, wektora wielkości prognozowanych oraz wektora parametrów [Osiewalski 2001]:

$$
p\left(y, y_{f}, \theta\right)=p\left(y, y_{f} \mid \theta\right) p(\theta)=p\left(y_{f} \mid y, \theta\right) p(y \mid \theta) p(\theta) .
$$

Przejdźmy do specyfikacji procesu Copula-AR(1)-GARCH(1,1). Proces stochastyczny $\left\{y_{t}=\left(y_{1, t}, y_{2, t}\right)^{\prime}, t=0,1,2, \ldots, T\right\}$ jest procesem Copula-AR(1)-GARCH $(1,1) \mathrm{z}$ warunkowymi rozkładami $t$-Studenta, jeżeli spełnia następujące równania:

$$
\begin{gathered}
y_{i, t}=\varphi_{i, 0}+\varphi_{i, 1} y_{i, t-1}+z_{i, t}, \\
z_{i, t}=\varepsilon_{i, t} \sqrt{h_{i, t}},
\end{gathered}
$$




$$
h_{i, t}=\alpha_{i, 0}+\alpha_{i, 1} z_{i, t-1}^{2}+\beta_{i, 1} h_{i, t-1},
$$

gdzie $i=1,2, t=1,2, \ldots, T, a_{i 0}>0, a_{i, 1}>0, \beta_{i, 1}>0,\left\{\varepsilon_{i, t}\right\}_{t=1}^{T} \sim i i t\left(0,1, v_{i}\right)$, czyli $\left\{\varepsilon_{i, t}, t=1,2, \ldots, T\right\}$ jest ciągiem niezależnych zmiennych losowych o rozkładzie $t$-Studenta z zerową modalną, jednostkową precyzją i $v_{i}$ stopniami swobody $\left(E\left(\varepsilon_{i, t}^{2}\right)=v_{i} /\left(v_{i}-2\right), v_{i}>2\right)$. Natomiast łączny rozkład wektora $\left(\varepsilon_{1, t}, \varepsilon_{2, t}\right)^{\prime}$ zadany jest poprzez kopulę o gęstości $c\left(u_{1}, u_{2}\right)$ [Patton 2006b, Jondeau i Rockinger 2006, Doman 2011, Mokrzycka i Pajor 2016].

W modelu Copula-AR(1)-GARCH(1,1) z warunkowymi skośnymi rozkładami $t$-Studenta $\left\{\varepsilon_{i, t}\right\}_{t=1}^{T} \sim i i S t\left(0,1, v_{i}, \gamma_{i}\right)$, gdzie $S t\left(0,1, v_{i}, \gamma_{i}\right)$ oznacza skośny rozkład $t$-Studenta z zerową modalną, jednostkową precyzją, $v_{i}$ stopniami swobody oraz parametrze asymetrii $\gamma_{i}$.

Kopula to funkcja określona na kostce $[0,1]^{n} \mathrm{o}$ wartościach w przedziale $[0,1]$, będąca obcięciem dystrybuanty $n$-wymiarowego rozkładu prawdopodobieństwa o jednostajnych rozkładach brzegowych na przedziale $[0,1]$ do kostki jednostkowej [Jaworski 2012, Durante i Sempi 2016, Doman 2011]. Podstawą do stosowania kopul w statystyce, a także w badaniach ekonometrycznych jest twierdzenie Sklara, który wykazał, że dla każdej $n$-wymiarowej dystrybuanty $H$ istnieje taka kopula $C$, że zachodzi następująca równość: $H\left(x_{1}, \ldots, x_{n}\right)=C\left(F_{1}\left(x_{1}\right), \ldots, F_{n}\left(x_{n}\right)\right)$, gdzie $F_{1}, \ldots, F_{n}$ są dystrybuantami brzegowymi. Ponadto, jeśli dystrybuanty brzegowe są ciągłe, to kopula $C$ wyznaczona jest jednoznacznie. Twierdzenie odwrotne do twierdzenia Sklara również jest prawdziwe, tzn. jeżeli $C$ jest $n$-wymiarową kopulą, a $F_{1}, \ldots, F_{n}$ są jednowymiarowymi dystrybuantami, to funkcja $H\left(x_{1}, \ldots, x_{n}\right)=$ $=C\left(F_{1}\left(x_{1}\right), \ldots, F_{n}\left(x_{n}\right)\right)$ jest $n$-wymiarową dystrybuantą, a $F_{1}, \ldots, F_{n}$ jej dystrybuantami brzegowymi [Nelsen 1999, Jaworski 2012]. Z kolei rozszerzenie tego twierdzenia na rozkłady warunkowe, $\mathrm{z}$ warunkową kopulą, zostało przedstawione przez A.J. Pattona w 2006 r. Stosowanie twierdzenia z rozkładami warunkowymi jest możliwe w przypadku, gdy zbiór informacji, względem którego odbywa się warunkowanie, jest taki sam dla warunkowej kopuli oraz warunkowych rozkładów brzegowych [Patton 2006b]. Współczynnik tau Kendalla ( $\tau$ ) oraz współczynniki $\lambda^{U}, \lambda^{L}$ zależności w ogonach rozkładów dwuwymiarowych dla wektora ciągłych zmiennych losowych $\left(X_{1}, X_{2}\right)$ o kopuli $C$ mogą zostać wyznaczone za pomocą następujących wzorów:

$$
\begin{gathered}
\tau\left(X_{1}, X_{2}\right)=4 \iint_{[0,1]^{2}} C\left(u_{1}, u_{2}\right) d C\left(u_{1}, u_{2}\right)-1, \\
\lambda^{U}=\lim _{a \rightarrow 1^{-}} \frac{2 \alpha-1+C(1-\alpha, 1-\alpha)}{\alpha}, \quad \lambda^{L}=\lim _{\alpha \rightarrow 0^{+}} \frac{C(\alpha, \alpha)}{\alpha} .
\end{gathered}
$$

W pracy wykorzystano przede wszystkim kopule, dla których współczynniki zależności ogonowych posiadają postać analityczną. Zestawienie kopul i postaci tych współczynników zawarto w tabeli 1 . Dobór kopul podyktowany był przede 
wszystkim uwzględnieniem tych typów, które, po pierwsze, dopuszczają asymetryczne wartości współczynników zależności w ogonach rozkładu, w tym zerową wartość jednego współczynnika, po drugie, obejmują klasycznie stosowane wielowymiarowe rozkłady $t$-Studenta.

Warunkowa gęstość wektora $\varepsilon_{t}=\left(\varepsilon_{1, t}, \varepsilon_{2, t}\right)$ w modelu Copula-AR(1)-GARCH(1,1) z warunkowymi rozkładami $t$-Studenta ma postać:

$$
\begin{gathered}
p_{\varepsilon}\left(\varepsilon_{1, t}, \varepsilon_{2, t} \mid \psi_{t-1}\right)=c\left(t_{v_{1}}\left(\varepsilon_{1, t} \mid \psi_{t-1}\right), t_{v_{2}}\left(\varepsilon_{2, t} \mid \psi_{t-1}\right) \mid \psi_{t-1}\right) f_{S t}\left(\varepsilon_{1, t} ; 0,1, v_{1} \mid \psi_{t-1}\right) \times \\
\times f_{S t}\left(\varepsilon_{2, t} ; 0,1, v_{2} \mid \psi_{t-1}\right),
\end{gathered}
$$

gdzie $t_{v}(\cdot)$ oznacza dystrybuantę jednowymiarowego rozkładu $t$-Studenta o zerowej modalnej, jednostkowej precyzji i $v$ stopniach swobody, zaś $f_{S t}(\cdot ; 0,1, v)$ jest gęstością tego rozkładu. Natomiast w przypadku zastosowania rozkładu skośnego $t$-Studenta dla $\varepsilon_{1, t}$ i $\varepsilon_{2, t}$ gęstość rozkładu prawdopodobieństwa wektora $\varepsilon_{t}$ ma postać:

$$
\begin{gathered}
p_{\varepsilon}\left(\varepsilon_{1, t}, \varepsilon_{2, t} \mid \psi_{t-1}\right)= \\
=c\left(t_{v_{1}, \gamma_{1}}\left(\varepsilon_{1, t} \mid \psi_{t-1}\right), t_{v_{2}, \gamma_{2}}\left(\varepsilon_{2, t} \mid \psi_{t-1}\right) \mid \psi_{t-1}\right) f_{S t, \gamma_{1}}\left(\varepsilon_{1, t} ; 0,1, v_{1}, \gamma_{1} \mid \psi_{t-1}\right) \times \\
\times f_{S t, \gamma_{2}}\left(\varepsilon_{2, t} ; 0,1, v_{2}, \gamma_{2} \mid \psi_{t-1}\right),
\end{gathered}
$$

gdzie $t_{v, \gamma}(\cdot)$ oznacza dystrybuantę jednowymiarowego rozkładu skośnego $t$-Studenta o zerowej modalnej, jednostkowej precyzji, $v$ stopniach swobody $(v>2)$ i parametrze asymetrii $\gamma>0$, zaś $f_{S t, \gamma}(\cdot ; 0,1, v, \gamma)$ jest gęstością tego rozkładu i ma następującą postać [Osiewalski 2001, Pipień 2006]:

$$
\begin{gathered}
f_{S t, \gamma}(x \mid v, \mu, h, \gamma)=\frac{2 \Gamma\left(\frac{v+1}{2}\right)}{\left(\gamma+\gamma^{-1}\right) \Gamma\left(\frac{v}{2}\right) \sqrt{\pi \nu}} \times \\
\times \sqrt{h^{-1}}\left[1+(v h)^{-1}(x-\mu)^{2}\left\{\gamma^{2} I_{(-\infty, 0)}(x-\mu)+\gamma^{-2} I_{[0, \infty)}(x-\mu)\right\}\right]^{-0,5(v+1))} .
\end{gathered}
$$

Z kolei łączny warunkowy rozkład wektora $\left(y_{1, t}, y_{2, t}\right)^{\prime} \operatorname{przy} \mu_{\mathrm{i}, t}=\varphi_{i, 0}+\varphi_{i, 1} y_{i, t-1}$, $i=1,2$ jest następujący:

$p_{I}\left(y_{1, t}, y_{2, t} \mid \psi_{t-1}\right)=p_{\varepsilon}\left(\left(y_{1, t}-\mu_{1, t}\right) / \sqrt{h_{1, t}},\left(y_{2, t}-\mu_{2, t}\right) / \sqrt{h_{2, t}} \mid \psi_{t-1}\right) / \sqrt{h_{1, t} h_{2, t}}$.

Wobec powyższego, oznaczając przez $\theta=\left(\theta_{G}{ }^{\prime}, \theta_{C}{ }^{\prime}\right)^{\prime} \in \Theta=\Theta_{G} \times \Theta_{C} \subset R^{m}$ wektor nieznanych parametrów modelu Copula-AR(1)-GARCH(1,1), gęstość łącznego rozkładu macierzy obserwacji ma postać:

$$
p\left(y \mid \theta_{G}, \theta_{C}\right)=\prod_{i=1}^{T} p_{y}\left(y_{1, t}, y_{2, t} \mid \psi_{t-1}\right),
$$


przy czym $\theta_{G}$ oznacza wektor parametrów struktury AR(1)-GARCH(1,1), $\theta_{C}$ wektor parametrów kopuli.

W bayesowskim modelu Copula-AR(1)-GARCH(1,1), w którym nieznane parametry traktowane są jako zmienne losowe, gęstość łącznego rozkładu macierzy obserwacji i parametrów ma postać:

$$
p\left(y, \theta_{G}, \theta_{C}\right)=p\left(y \mid \theta_{G}, \theta_{C}\right) p\left(\theta_{G}, \theta_{C}\right),
$$

gdzie $p(\theta)=p\left(\theta_{G}, \theta_{C}\right)$ jest gęstością rozkładu a priori wektora $\theta, p\left(y \mid \theta_{G}, \theta_{C}\right)$ jest tzw. gęstością próbkową macierzy obserwacji, która w przypadku analizowanego modelu w swojej postaci zawiera gęstość określonej warunkowej kopuli oraz gęstości warunkowych rozkładów brzegowych (por. równanie (7)).

W dalszej części pracy przyjęto, że gęstość rozkładu a priori nieznanych parametrów modelu Copula-AR(1)-GARCH(1,1) dla struktury AR(1)-GARCH(1,1), czyli wektora:

$$
\theta_{G}=\left(\varphi_{1,0}, \varphi_{1,1}, \alpha_{1,0}, \alpha_{1,1}, \beta_{1,1}, \gamma_{1}, v_{1}, \varphi_{2,0}, \varphi_{2,1}, \alpha_{2,0}, \alpha_{2,1}, \beta_{2,1}, \gamma_{2}, v_{2}\right),
$$

ma postać

$$
p\left(\theta_{G}\right)=p\left(\varphi_{1,0}, \varphi_{2,0}\right) p\left(\varphi_{1,1}, \varphi_{2,1}\right) \prod_{i=1}^{2} p\left(\alpha_{i, 0}\right) p\left(\alpha_{i, 1}, \beta_{i, 1}\right) p\left(\gamma_{i}\right) p\left(v_{i}\right),
$$

gdzie

$$
\begin{aligned}
p\left(\varphi_{1,0}, \varphi_{2,0}\right) & =f_{N, 2}\left(\varphi_{1,0}, \varphi_{2,0} \mid(0,0)^{\prime}, I\right) ; p\left(\varphi_{1,1}, \varphi_{2,1}\right)=\frac{1}{4} I_{(-1,1)^{2}}\left(\varphi_{1,1}, \varphi_{2,1}\right) ; \\
p\left(\alpha_{i, 0}\right) & =f_{E x p}\left(\alpha_{i, 0} \mid \lambda_{\alpha}\right), \lambda_{\alpha}=1 ; p\left(\alpha_{i, 1}, \beta_{i, 1}\right)=\frac{1}{2} I_{B}\left(\alpha_{i, 1}, \beta_{i, 1}\right) ; \\
B & =[0,1]^{2} \cap\left\{(x, y)^{\prime}: x+y<1\right\} ; p\left(\gamma_{i}\right)=f_{L N}\left(\gamma_{i} \mid 0,1\right),
\end{aligned}
$$

przy czym $f_{L N}$ to gęstość rozkładu log-normalnego o parametrach $\mu=0, \sigma=1$;

$$
p\left(v_{i}\right)=\frac{1}{\sigma_{v}} \exp \left(-\frac{x-\mu_{v}}{\sigma_{v}}\right) I_{\left(\mu_{v}, \infty\right)}\left(v_{i}\right) ; \mu_{v}=2 ; \sigma_{v}=8 ; E\left(v_{i}\right)=10, i=1,2 .
$$

Gęstość rozkładu a priori przyjęto tak, by ograniczyć wnoszenie istotnych informacji do modelu, wzorując się na badaniach prowadzonych przez A. Pajor [2003] oraz M. Pipienia [2006]. Podobnie dobór gęstości rozkładu a priori dla parametrów poszczególnych kopul miał na celu przyjęcie rozkładów, które nie wnosiłyby istotnych informacji do modelu, stąd też przyjęto rozkłady, dla których współczynnik tau Kendalla ma dość rozproszony rozkład (zbliżony do rozkładu jednostajnego). Doboru typów rozkładów i wartości parametrów dokonano za pomocą symulacji [Mokrzycka i Pajor 2016]. Zestawienie tych rozkładów przedstawiono w tabeli 1. 


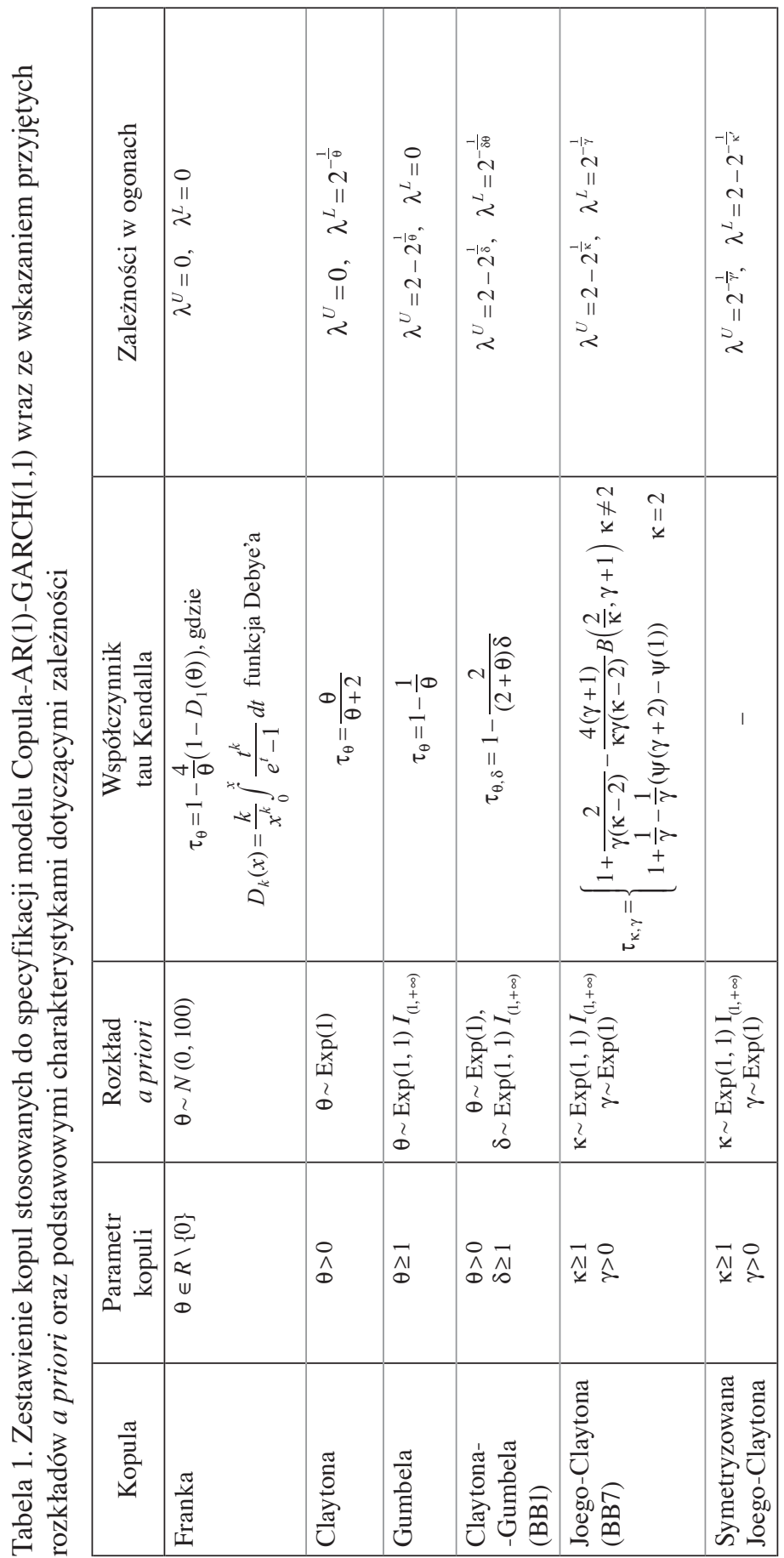




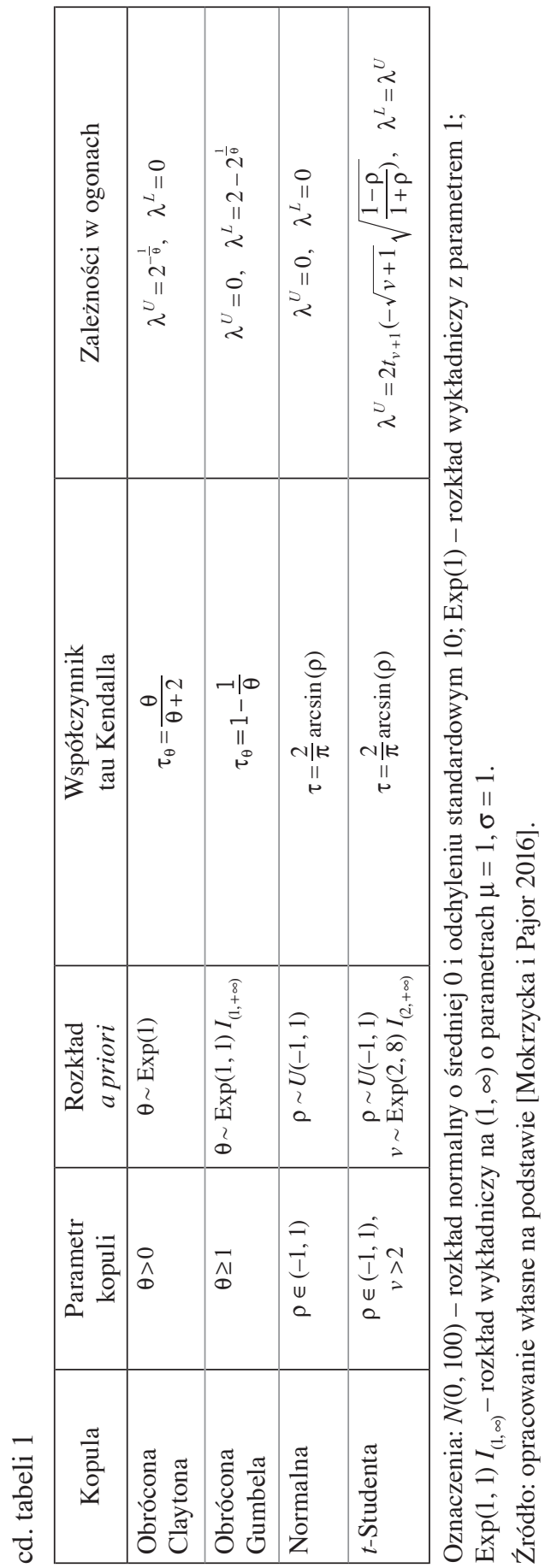




\section{Estymacja i porównanie modeli bayesowskich}

Podstawą wnioskowania w modelach bayesowskich są zasady rachunku prawdopodobieństwa oraz twierdzenie Bayesa. Estymacja parametrów modelu statystycznego polega na wyznaczeniu - z gęstości $p\left(y, \theta_{G}, \theta_{C}\right)=p\left(y \mid \theta_{G}, \theta_{C}\right) p\left(\theta_{G}, \theta_{C}\right)-$ rozkładu warunkowego wektora zmiennych losowych $\theta=\left(\theta_{G}, \theta_{C}\right)$ przy ustalonym wektorze obserwacji $y$, czyli tzw. rozkładu a posteriori:

$$
p(\theta \mid y)=\frac{p(y, \theta)}{p(y)}=\frac{p(y \mid \theta) p(\theta)}{\int_{\theta} p(y \mid \theta) p(\theta) d \theta},
$$

gdzie $p(y)=\int_{\theta} p(y \mid \theta) p(\theta) d(\theta)$ jest brzegową gęstością wektora obserwacji. $\mathrm{W}$ modelu bayesowskim rozkład a posteriori łączy wstępną wiedzę badacza dotyczącą parametrów $\theta=\left(\theta_{G}, \theta_{C}\right)$ z informacją, jaką niosą dane empiryczne, określaną przez gęstość $p(y \mid \theta)$ [Pajor 2003].

Porównanie konkurencyjnych modeli bayesowskich wymaga obliczenia, na podstawie wzoru Bayesa, prawdopodobieństwa a posteriori tych modeli [Osiewalski 2001]. Niech $M=\left\{M_{1}, \ldots, M_{n}\right\}$ będzie kompletnym zbiorem wzajemnie rozłącznych modeli bayesowskich: $M_{i}: p_{i}\left(y, \theta_{(i)}\right)=p_{i}\left(y \mid \theta_{(i)}\right) p_{i}\left(\theta_{(i)}\right), i=1, \ldots, m$, gdzie $\theta_{(i)} \in \Theta$ jest wektorem parametrów modelu $M_{i}$. Prawdopodobieństwo a posteriori modelu, wyznaczone na podstawie wzoru Bayesa, jest postaci:

$$
p\left(M_{i} \mid y\right)=\frac{p\left(M_{i}\right) p\left(y \mid M_{i}\right)}{\sum_{j=1}^{n} p\left(M_{i}\right) p\left(y \mid M_{j}\right)}, \quad i=1, \ldots, m
$$

gdzie $p\left(M_{i}\right)$ to prawdopodobieństwo a priori modelu $M_{i}, p\left(y \mid M_{i}\right)$ to brzegowa gęstość macierzy obserwacji w modelu $M_{i}: p\left(y \mid M_{i}\right)=p_{i}(y)=\int_{\Theta} p_{i}\left(y \mid \theta_{(i)}\right) p_{i}\left(\theta_{(i)}\right) d \theta_{(i)}$. Model z najwyższym prawdopodobieństwem a posteriori uznawany jest za model najlepiej wyjaśniający dane empiryczne. Z kolei dobór prawdopodobieństw a priori modeli $p\left(M_{i}\right)$ sprowadza się najczęściej do przyjęcia, że są one jednakowe, lub do nadania wyższych prawdopodobieństw modelom o mniejszej liczbie parametrów, zgodnie z tzw. zasadą brzytwy Ockhama [Osiewalski 2001].

Jeżeli głównym celem badawczym jest wnioskowanie o parametrach wspólnych dla wszystkich modeli (np. wnioskowanie o współczynniku tau Kendalla), możliwe jest pominięcie wyboru najbardziej prawdopodobnego modelu i zastosowanie techniki bayesowskiego łączenia wiedzy (Bayesian pooling approach). Metoda sprowadza się do obliczenia średniej ważonej poszczególnych gęstości a posteriori wspólnych parametrów z wagami równymi prawdopodobieństwom a posteriori modeli [Osiewalski 2001]. Gęstość a posteriori dla wektora wspólnych parametrów $\lambda$ ma wówczas postać: $p(\lambda \mid y)=\sum_{i=1}^{n} p\left(M_{i} \mid y\right) p_{i}(\lambda \mid y)$, gdzie $p\left(M_{i} \mid y\right)$ jest prawdopodobieństwem a posteriori obliczonym zgodnie ze wzorem (8), $p_{i}(\lambda \mid y)$ 
jest gęstością brzegowego rozkładu a posteriori wektora $\lambda$ w modelu $M_{i}$. Zastosowanie bayesowskiego łączenia wiedzy pozwala na uwzględnienie zarówno niepewności co do wartości nieznanego parametru, jak i przez uśrednienie wiedzy o wspólnych parametrach, niepewności co do prawidłowej specyfikacji modelu w skończonej klasie modeli [Osiewalski 2001].

\section{Losowanie z funkcją ważności}

Wyznaczenie charakterystyk rozkładu a posteriori w modelu bayesowskim w jawnej postaci nie zawsze jest możliwe z uwagi na skomplikowaną postać gęstości rozkładu a posteriori tego rozkładu. Wobec tego do wyznaczenia tych charakterystyk stosuje się numeryczne metody całkowania. Najczęściej stosowane w kontekście wnioskowania bayesowskiego są metody Monte Carlo [Osiewalski 2001, Pajor 2003, Pipień 2006]. W niniejszej pracy z uwagi na niedużą liczbę parametrów zastosowano metodę Monte Carlo z funkcją ważności (Monte Carlo Importance Sampling). Metoda ta była jedną z pierwszych metod stosowanych w ekonometrii bayesowskiej [Kloek i van Dijk 1978].

Ponieważ $p(\theta \mid y)=\frac{p(y \mid \theta) p(\theta)}{\int_{\Theta} p(y \mid \theta) p(\theta) d \theta}$, więc gęstość rozkładu a posteriori wektora

parametrów modelu, $\theta$, jest proporcjonalna do iloczynu $f(\theta)=p(y \mid \theta) p(\theta)$. Wyznaczenie charakterystyk rozkładu a posteriori wektora parametrów $\theta$ sprowadza się do obliczenia wartości oczekiwanych, względem rozkładu a posteriori, pewnych funkcji wektora $\theta$ [Osiewalski 2001, Pipień 2006]. Niech $g$ oznacza tę funkcję, a $s$ będzie gęstością pewnego rozkładu, wówczas:

$$
\begin{aligned}
I=E(g(\theta) \mid y) & =\int_{\Theta} g(\theta) p(\theta \mid y) d \theta=\frac{\int_{\Theta} g(\theta) f(\theta) d \theta}{\int_{\Theta} f(\theta) d \theta}= \\
& =\frac{\int_{\Theta} g(\theta) \frac{f(\theta)}{s(\theta)} d S(\theta)}{\int_{\Theta} \frac{f(\theta)}{S(\theta)} d S(\theta)},
\end{aligned}
$$

gdzie $d S(\theta)$ oznacza całkowanie względem absolutnie ciągłej miary probabilistycznej $S$ określonej na $\sigma$-algebrze zbioru $\Theta$, o dodatniej funkcji gęstości $s$ [Pipień 2006]. Wobec powyższego obliczenie szukanej wartości oczekiwanej $I$ sprowadza się do obliczenia ilorazu dwóch wartości oczekiwanych względem znanej miary $S$, które to z kolei możemy estymować za pomocą średnich z próby. Estymator Monte Carlo wielkości I ma postać [Osiewalski 2001, Pipień 2006]: 


$$
\widehat{I_{n}}=\frac{\frac{1}{n} \sum_{i=1}^{n} \frac{g\left(\theta^{(i)}\right) f\left(\theta^{(i)}\right)}{s\left(\theta^{(i)}\right)}}{\frac{1}{n} \sum_{i=1}^{n} \frac{f\left(\theta^{(i)}\right)}{s\left(\theta^{(i)}\right)}}=\frac{\sum_{i=1}^{n} g\left(\theta^{(i)}\right) w\left(\theta^{(i)}\right)}{\sum_{i=1}^{n} w\left(\theta^{(i)}\right)},
$$

gdzie $w(\theta)=\frac{f(\theta)}{s(\theta)}$ oznacza tzw. funkcję wagową.

Jeżeli funkcja $f$ jest proporcjonalna do gęstości właściwego rozkładu prawdopodobieństwa oraz $\theta^{(1)}, \ldots, \theta^{(n)} \in \Theta$ są losowane niezależnie z rozkładu o gęstości $s$ oraz wartość oczekiwana $E(g \mid y)$ istnieje i jest skończona, to zachodzi zbieżność prawie wszędzie: $\widehat{I_{n}} \rightarrow E(g \mid y), n \rightarrow \infty$ (estymator jest zgodny). Ponadto przy spełnieniu pewnych warunków podanych m.in. w pracy [Geweke 1989] estymator ten jest asymptotycznie normalny.

Stosowanie metod Monte Carlo związane jest z obecnością błędów numerycznych. Standardowy błąd numeryczny metody Monte Carlo (NSE, numerical standard error) postaci $\widehat{\phi_{n}}=\sqrt{\frac{\sum_{i=1}^{n}\left(g\left(\theta^{(i)}\right)-\widehat{I}_{n}\right)^{2} w\left(\theta^{(i)}\right)^{2}}{\left(\sum_{i=1}^{n} w\left(\theta^{(i)}\right)\right)^{2}}}$ powinien osiągać wartości zerowe. Estymator współczynnika RNE (relative numerical efficiency, względnej efektywności numerycznej) postaci $\widehat{R N E}=\frac{1}{n{\widehat{\phi_{n}^{2}}}^{2}}\left[\frac{\sum_{i=1}^{n} g^{2}\left(\theta^{(i)}\right) w\left(\theta^{(i)}\right)}{\sum_{i=1}^{n} w\left(\theta^{(i)}\right)}-\widehat{I}_{n}^{2}\right]$ powinien przyjmować wartości bliskie jeden, co zachodzi wówczas, gdy losowanie według funkcji ważności prawie nie różni się od losowania z rozkładu a posteriori [Osiewalski 2001]. Z kolei współczynnik zmienności funkcji wagowej $\gamma_{n}=\frac{\sqrt{\sum_{i=1}^{n} \frac{w^{2}\left(\theta^{(i)}\right)}{n}-\left(\sum_{i=1}^{n} \frac{w\left(\theta^{(i)}\right)}{n}\right)^{2}}}{\frac{1}{n} \sum_{i=1}^{n} w\left(\theta^{(i)}\right)}$ określa stosunek empirycznego odchylenia standardowego wartości wag do średniej wagi. Nieograniczony wzrost tego współczynnika wraz ze wzrostem liczby losowań, obserwowany w postaci nagłych skoków jego wartości, wskazuje, że dobrana funkcja ważności jest nieodpowiednia [Osiewalski 2001].

W zastosowaniach metody Monte Carlo dobór funkcji ważności jest bardzo ważny - im funkcja ważności lepiej przybliża jądro gęstości rozkładu a posteriori, tym uzyskiwane realizacje „,nieznacznie” różnią się od realizacji z rzeczywistego rozkładu a posteriori, co skutkuje dobrymi aproksymacjami numerycznymi. W niniejszej pracy za funkcję ważności przyjęto wielowymiarowy rozkład $t$-Studenta z 3 stopniami swobody zgodnie z pracami J. Osiewalskiego [2001] i M. Pipienia [2006]. Parametry tego rozkładu (wektor średnich i macierz kowa- 
riancji) zostały oszacowane iteracyjnie na podstawie wstępnych 100 tys. lub $1 \mathrm{mln}$ przebiegów algorytmu.

Stosowanie metody Monte Carlo z funkcją ważności znacznie upraszcza sposób szacowania wartości brzegowej gęstości macierzy obserwacji $p(y)$, gdyż jej estymatorem jest średnia arytmetyczna wag: $\frac{1}{n} \sum_{i=1}^{n} w\left(\theta^{(i)}\right)$. Warto zaznaczyć, że stosowanie algorytmu Metropolisa-Hastingsa wymaga zastosowania bardziej czasochłonnych (obliczeniowo) estymatorów, np. skorygowanej średniej harmonicznej, estymatora Chiba i Jeliazkova, estymatora Laplace'a i Metropolisa czy skorygowanej średniej arytmetycznej [Mokrzycka i Pajor 2016, Pajor 2017].

\section{Wyniki empiryczne}

Przedmiotem modelowania jest zmienność i struktura zależności dziennych, procentowych logarytmicznych stóp zwrotu, obliczonych na podstawie ceny zamknięcia subindeksów indeksu WIG - WIG-Budownictwo (WIGBUD) i WIG-Informatyka (WIGINF) w okresie od 1.08.2005 do 21.09.2015. Wybór tego okresu wynika z kontynuacji badań nad strukturą zależności dla subindeksów indeksu WIG zaprezentowanych w pracy [Mokrzycka i Pajor 2016]. Liczba obserwacji (stóp zwrotu) szeregu subindeksów wyniosła 2539. Dane pochodziły z portalu www.stooq.pl. Na rys. 1 przedstawiono wykresy oraz charakterystyki próbkowe logarytmicznych procentowych stóp zwrotu.

Wykresy analizowanych szeregów czasowych obrazują występowanie okresów skupiania się zmienności (volatility clustering), czyli okresów o dużych co do wartości bezwzględnej stopach zwrotu, po których następują okresy o mniejszych wartościach stóp zwrotu. Współczynniki skośności wskazują na występowanie lewostronnej asymetrii rozkładu. Wartość kurtozy: 5,8886 i 6,4209 wskazuje na leptokurtyczność rozkładów empirycznych (duża koncentracja rozkładu wokół modalnej oraz występowanie grubych ogonów). Histogramy rozkładów empirycznych wraz z wykresami gęstości rozkładu normalnego o średnich i wariancjach z próby (rys. 2), obrazują występowanie obserwacji nietypowych (przekraczających trzykrotność odchylenia standardowego od średniej). Prezentowane wykresy sugerują dobór rozkładów o grubych ogonach.

Wartość współczynnika korelacji liniowej wynosi 0,5480, a współczynnika tau Kendalla - 0,3384. Wartości te sugerują dodatnią zależność.

Wyniki zamieszczone w tabelach 2-4 przedstawiają wartości logarytmu naturalnego brzegowej gęstości a posteriori macierzy obserwacji $(\ln (p(y \mid M)))$ oraz wartości prawdopodobieństwa a posteriori poszczególnych modeli, przy założeniu, że a priori modele są jednakowo prawdopodobne. 


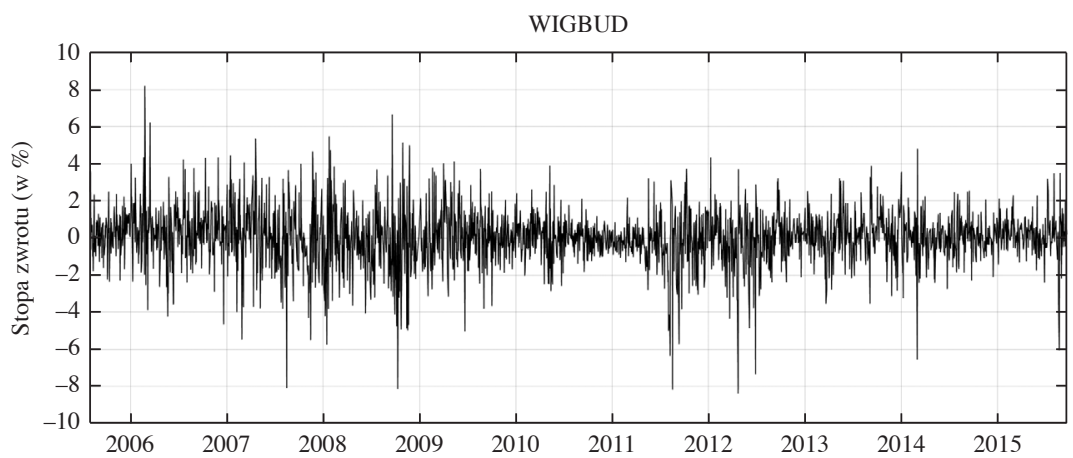

Średnia: 0,009; odchylenie standardowe: 1,4833; skośność: -0,3697; kurtoza: 6,4209; Min:-8,3796, Max: 8,2028

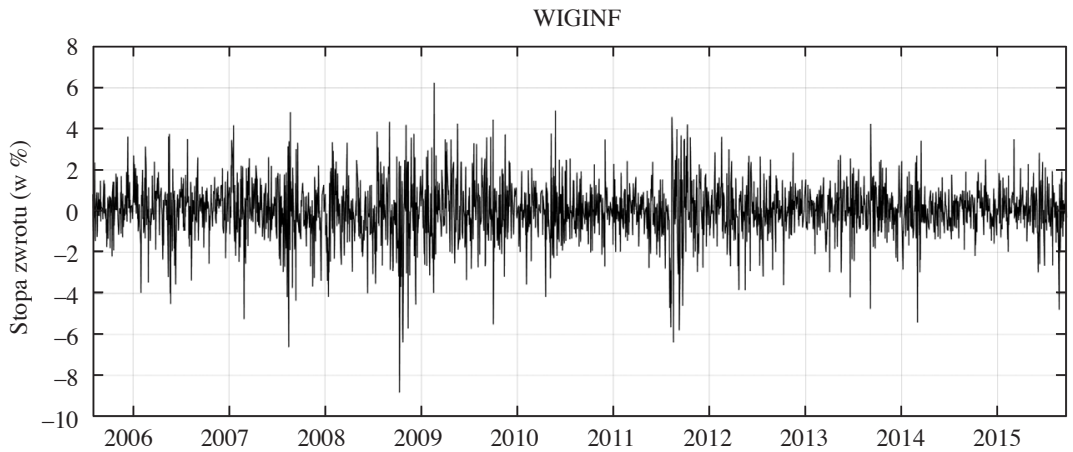

Średnia: 0,013; odchylenie standardowe: 1,3495; skośność: -0,4282; kurtoza: 5,8886; Min: -8,8167, Max: 6,2388

Rys. 1. Wykresy oraz charakterystyki próbkowe logarytmicznych procentowych stóp zwrotu Źródło: opracowanie własne.

a)

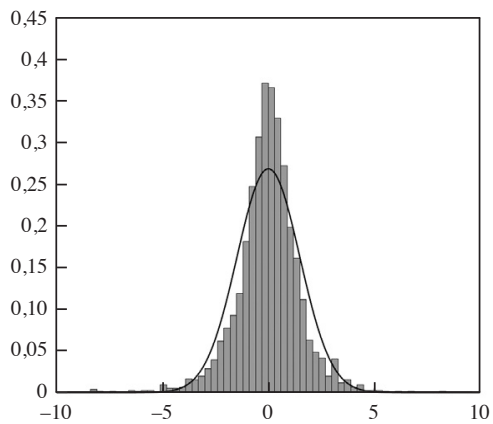

b)

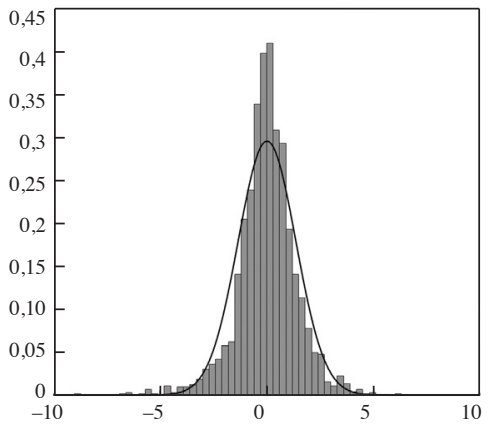

Rys. 2. Rozkłady empiryczne analizowanych szeregów z dopasowaną gęstością rozkładu normalnego: a) WIGBUD, b) WIGINF

Źródło: opracowanie własne. 
Tabela 2. Prawdopodobieństwa a posteriori modeli Copula-AR(1)-GARCH(1,1) z warunkowymi brzegowymi rozkładami $t$-Studenta

\begin{tabular}{|c|l|c|c|c|}
\hline Lp. & \multicolumn{1}{|c|}{ Kopula } & $\ln (p(y \mid M))$ & $p(M)$ & $p(M \mid y)$ \\
\hline 1 & Franka & $-8145,407$ & 0,0909 & 0 \\
\hline 2 & Claytona & $-8128,834$ & 0,0909 & 0 \\
\hline 3 & Gumbela & $-8149,97$ & 0,0909 & 0 \\
\hline 4 & Claytona-Gumbela (BB1) & $-8083,948$ & 0,0909 & 0,71061 \\
\hline 5 & Joe-Claytona (BB7) & $-8086,289$ & 0,0909 & 0,06838 \\
\hline 6 & Symetryzowana Joe-Claytona & $-8085,13$ & 0,0909 & 0,2178 \\
\hline 7 & Obrócona Claytona & $-8128,838$ & 0,0909 & 0 \\
\hline 8 & Obrócona Gumbela & $-8092,694$ & 0,0909 & 0,00011 \\
\hline 9 & Normalna & $-8105,155$ & 0,0909 & 0 \\
\hline 10 & $t$-Studenta & $-8089,383$ & 0,0909 & 0,0031 \\
\hline 11 & Zmiennych niezależnych & $-8452,584$ & 0,0909 & 0 \\
\hline
\end{tabular}

Źródło: opracowanie własne.

Tabela 3. Prawdopodobieństwa a posteriori modeli Copula-AR(1)-GARCH(1,1) z warunkowymi brzegowymi rozkładami skośnymi $t$-Studenta

\begin{tabular}{|c|l|c|c|c|}
\hline Lp. & \multicolumn{1}{|c|}{ Kopula } & $\ln (p(y \mid M))$ & $p(M)$ & $p(M \mid y)$ \\
\hline 1 & Franka & $-8148,594$ & 0,0909 & 0 \\
\hline 2 & Claytona & $-8131,529$ & 0,0909 & 0 \\
\hline 3 & Gumbela & $-8157,282$ & 0,0909 & 0 \\
\hline 4 & Claytona-Gumbela (BB1) & $-8089,403$ & 0,0909 & 0,7164 \\
\hline 5 & Joe-Claytona (BB7) & $-8091,892$ & 0,0909 & 0,0595 \\
\hline 6 & Symetryzowana Joe-Claytona & $-8090,584$ & 0,0909 & 0,2199 \\
\hline 7 & Obrócona Claytona & $-8228,252$ & 0,0909 & 0 \\
\hline 8 & Obrócona Gumbela & $-8094,758$ & 0,0909 & 0,0034 \\
\hline 9 & Normalna & $-8111,274$ & 0,0909 & 0,0000 \\
\hline 10 & $t$-Studenta & $-8096,188$ & 0,0909 & 0,0008 \\
\hline 11 & Zmiennych niezależnych & $-8455,067$ & 0,0909 & 0 \\
\hline
\end{tabular}

Źródło: opracowanie własne.

Wartości brzegowych gęstości a posteriori macierzy obserwacji zostały oszacowane z wykorzystaniem metody Monte Carlo z funkcją ważności (gęstością wielowymiarowego rozkładu $t$-Studenta z 3 stopniami swobody) z zachowaniem odpowiedniej korekty wartości z uwagi na restrykcje narzucone na wartości parametrów każdego z modeli [Osiewalski 2001]. Po ustaleniu charakterystyk funkcji ważności (wektora średnich i macierzy precyzji) wykonano $1 \mathrm{mln}$ symulacji 
w ramach każdego modelu. W tabelach 2 i 3 zaprezentowano wyniki porównania 11 modeli Copula-AR(1)-GARCH(1,1) z, odpowiednio, warunkowym brzegowym rozkładem $t$-Studenta i warunkowym brzegowym skośnym rozkładem $t$-Studenta. Dla stóp zwrotu subindeksów WIG-Budownicto i WIG-Informatyka najbardziej prawdopodobny a posteriori jest model z kopulą Claytona-Gumbela. Model AR(1)-GARCH(1,1) z kopulą niezależną uzyskał zerowe prawdopodobieństwo a posteriori, modele opisujące niezależne struktury są zdecydowanie odrzucane. W tabeli 4 przedstawiono wyniki porównania wszystkich 22 modeli. Najwyższe wartości prawdopodobieństw a posteriori osiągnęły modele z brzegowym warunkowym symetrycznym rozkładem $t$-Studenta i kopulą Claytona-Gumbela. Niskie prawdopodobieństwo a posteriori modeli ze skośnym rozkładem $t$-Studenta potwierdza stwierdzenie zamieszczone w pracy [Mokrzycka i Pajor 2016, s. 136], że „na wartość współczynnika skośności mają wpływ obserwacje znajdujące się daleko w lewym ogonie".

Tabela 4. Prawdopodobieństwa a posteriori modeli

\begin{tabular}{|c|c|c|c|c|c|}
\hline Lp. & \multicolumn{2}{|l|}{ Kopula } & $\ln (p(y \mid M))$ & $p(M)$ & $p(M \mid y)$ \\
\hline 1 & \multirow[t]{2}{*}{ Franka } & $\mathrm{t}$ & $-8145,407$ & 0,0455 & 0 \\
\hline 2 & & t-sk & $-8148,594$ & 0,0455 & 0 \\
\hline 3 & \multirow[t]{2}{*}{ Claytona } & $\mathrm{t}$ & $-8128,834$ & 0,0455 & 0 \\
\hline 4 & & t-sk & $-8131,529$ & 0,0455 & 0 \\
\hline 5 & \multirow[t]{2}{*}{ Gumbela } & $\mathrm{t}$ & $-8149,97$ & 0,0455 & 0 \\
\hline 6 & & t-sk & $-8157,282$ & 0,0455 & 0 \\
\hline 7 & \multirow{2}{*}{$\begin{array}{l}\text { Claytona-Gumbela } \\
\text { (BB1) }\end{array}$} & $\mathrm{t}$ & $-8083,948$ & 0,0455 & 0,7076 \\
\hline 8 & & t-sk & $-8089,403$ & 0,0455 & 0,0030 \\
\hline 9 & \multirow[t]{2}{*}{ Joe-Claytona (BB7) } & $\mathrm{t}$ & $-8086,289$ & 0,0455 & 0,0681 \\
\hline 10 & & t-sk & $-8091,892$ & 0,0455 & 0,0003 \\
\hline 11 & \multirow{2}{*}{$\begin{array}{l}\text { Symetryzowana } \\
\text { Joe-Claytona }\end{array}$} & $\mathrm{t}$ & $-8085,13$ & 0,0455 & 0,2169 \\
\hline 12 & & t-sk & $-8090,584$ & 0,0455 & 0,0009 \\
\hline 13 & \multirow[t]{2}{*}{ Obrócona Claytona } & $\mathrm{t}$ & $-8128,838$ & 0,0455 & 0 \\
\hline 14 & & t-sk & $-8228,252$ & 0,0455 & 0 \\
\hline 15 & \multirow[t]{2}{*}{ Obrócona Gumbela } & $\mathrm{t}$ & $-8092,694$ & 0,0455 & 0,0001 \\
\hline 16 & & t-sk & $-8094,758$ & 0,0455 & 0,0000 \\
\hline 17 & \multirow[t]{2}{*}{ Normalna } & $\mathrm{t}$ & $-8105,155$ & 0,0455 & 0 \\
\hline 18 & & t-sk & $-8111,274$ & 0,0455 & 0 \\
\hline 19 & \multirow[t]{2}{*}{$t$-Studenta } & $\mathrm{t}$ & $-8089,383$ & 0,0455 & 0,0031 \\
\hline 20 & & t-sk & $-8096,188$ & 0,0455 & 0 \\
\hline 21 & \multirow{2}{*}{$\begin{array}{l}\text { Zmiennych } \\
\text { niezależnych }\end{array}$} & $\mathrm{t}$ & $-8452,584$ & 0,0455 & 0 \\
\hline 22 & & t-sk & $-8455,067$ & 0,0455 & 0 \\
\hline
\end{tabular}

Oznaczenia: $\mathrm{t}$ - model $\mathrm{z}$ warunkowym brzegowym rozkładem $t$-Studenta, $\mathrm{t}$-sk - model $\mathrm{z}$ warunkowym brzegowym skośnym rozkładem $t$-Studenta.

Źródło: opracowanie własne. 
Tabela 5. Charakterystyki a posteriori oraz NSE i RNE dla wartości oczekiwanych parametrów modeli

\begin{tabular}{|c|c|c|c|c|c|c|c|c|}
\hline \multirow[t]{2}{*}{ Parametr } & \multicolumn{4}{|c|}{$\begin{array}{c}\text { Copula-AR(1)-GARCH }(1,1) \\
\text { z brzegowymi rozkładami } t \text {-Studenta } \\
\text { i kopulą Claytona-Gumbela (BB1) }\end{array}$} & \multicolumn{4}{|c|}{$\begin{array}{c}\text { Copula-AR(1)-GARCH(1,1) } \\
\text { z brzegowymi rozkładami skośnymi } \\
t \text {-Studenta i kopulą Claytona-Gumbela } \\
\text { (BB1) }\end{array}$} \\
\hline & $E(\mid y)$ & $D(\mid y)$ & NSE & RNE & $E(\mid y)$ & $D(\mid y)$ & NSE & RNE \\
\hline$\varphi_{1,0}$ & 0,028 & 0,023 & $5,7 \mathrm{E}-05$ & 0,1586 & 0,065 & 0,041 & $1,1 \mathrm{E}-04$ & 0,144 \\
\hline$\varphi_{1,1}$ & 0,072 & 0,018 & $4,5 \mathrm{E}-05$ & 0,1573 & 0,071 & 0,018 & 4,7E-05 & 0,141 \\
\hline$\alpha_{1,0}$ & 0,024 & 0,008 & $3,2 \mathrm{E}-05$ & 0,0662 & 0,024 & 0,008 & $3,3 \mathrm{E}-05$ & 0,067 \\
\hline$\alpha_{1,1}$ & 0,031 & 0,007 & $2,4 \mathrm{E}-05$ & 0,0862 & 0,032 & 0,007 & $2,4 \mathrm{E}-05$ & 0,085 \\
\hline$\beta_{1,1}$ & 0,931 & 0,016 & $5,7 \mathrm{E}-05$ & 0,0760 & 0,929 & 0,016 & $6,0 \mathrm{E}-05$ & 0,073 \\
\hline$v_{1}$ & 5,242 & 0,511 & 0,00149 & 0,1170 & 5,223 & 0,508 & $1,5 \mathrm{E}-03$ & 0,114 \\
\hline$\varphi_{2,0}$ & 0,048 & 0,022 & $5,4 \mathrm{E}-05$ & 0,1574 & 0,109 & 0,039 & $1,0 \mathrm{E}-04$ & 0,148 \\
\hline$\varphi_{2,1}$ & $-0,043$ & 0,018 & $4,6 \mathrm{E}-05$ & 0,1564 & $-0,045$ & 0,018 & 4,9E-05 & 0,136 \\
\hline$\alpha_{2,0}$ & 0,046 & 0,015 & $5,9 \mathrm{E}-05$ & 0,0626 & 0,045 & 0,014 & $4,8 \mathrm{E}-05$ & 0,091 \\
\hline$\alpha_{2,1}$ & 0,040 & 0,009 & $2,7 \mathrm{E}-05$ & 0,1031 & 0,041 & 0,009 & 2,7E-05 & 0,102 \\
\hline$\beta_{2,1}$ & 0,896 & 0,024 & $9,1 \mathrm{E}-05$ & 0,0692 & 0,895 & 0,023 & $7,6 \mathrm{E}-05$ & 0,095 \\
\hline$v_{2}$ & 5,316 & 0,542 & 0,00157 & 0,1189 & 5,395 & 0,566 & 1,9E-03 & 0,092 \\
\hline$\theta_{1}$ & 0,427 & 0,043 & 0,00011 & 0,1572 & 0,460 & 0,048 & $1,3 \mathrm{E}-04$ & 0,135 \\
\hline$\theta_{2}$ & 1,217 & 0,027 & $6,9 \mathrm{E}-05$ & 0,1537 & 1,203 & 0,027 & $7,2 \mathrm{E}-05$ & 0,141 \\
\hline$\gamma_{1}$ & - & - & - & - & 0,972 & 0,023 & $6,1 \mathrm{E}-05$ & 0,138 \\
\hline$\gamma_{2}$ & - & - & - & - & 0,956 & 0,022 & $5,8 \mathrm{E}-05$ & 0,147 \\
\hline
\end{tabular}

Oznaczenia: $E(\mid y)$ - wartość oczekiwana, $D(\mid y)$ - odchylenie standardowe.

Źródło: opracowanie własne.

W tabeli 5 przedstawiono charakterystyki a posteriori dla wartości oczekiwanych parametrów najbardziej prawdopodobnych modeli oraz błędy numeryczne oszacowań (NSE i RNE). Na rys. 3 przedstawiono współczynnik zmienności wag - na osi poziomej jako jednostkę przyjęto 1000 iteracji. Uzyskane i przedstawione błędy numeryczne w ocenie autorki są do zaakceptowania. Błąd NSE przyjmuje wartości bliskie zeru, a współczynniki zmienności wag $\gamma_{n}$ nie wykazują nagłych dużych skoków wartości, jedynie RNE nie jest bliskie jeden, co oznacza, że istnieje możliwość dobrania lepszej funkcji ważności, która efektywniej „typowałaby" obserwacje z faktycznego rozkładu a posteriori.

Na rys. 4 zaprezentowano histogramy brzegowych rozkładów a posteriori wraz $\mathrm{z}$ rozkładem a priori parametrów asymetrii $\gamma_{1} \mathrm{i} \gamma_{2}$ uzyskane w modelu z kopulą Claytona-Gumbela. Rozkłady tych parametrów są przesunięte nieco w lewo od 1 , jedynka znajduje się w obszarze wysokich wartości funkcji gęstości rozkładu a posteriori. 

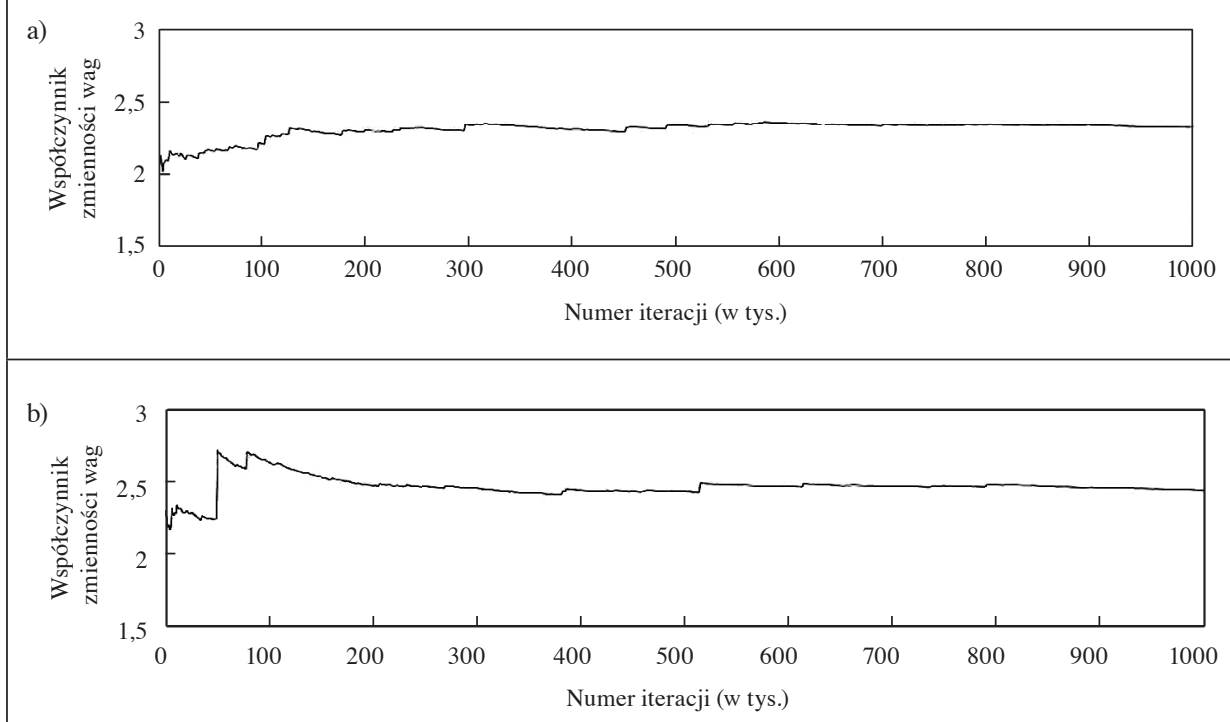

Rys. 3. Współczynniki zmienności wag w estymacji modelu Copula-AR(1)-GARCH(1,1): a) z brzegowymi rozkładami $t$-Studenta i kopulą Claytona-Gumbela, b) z brzegowymi rozkładami skośnymi $t$-Studenta i kopulą Claytona-Gumbela

Źródło: opracowanie własne.
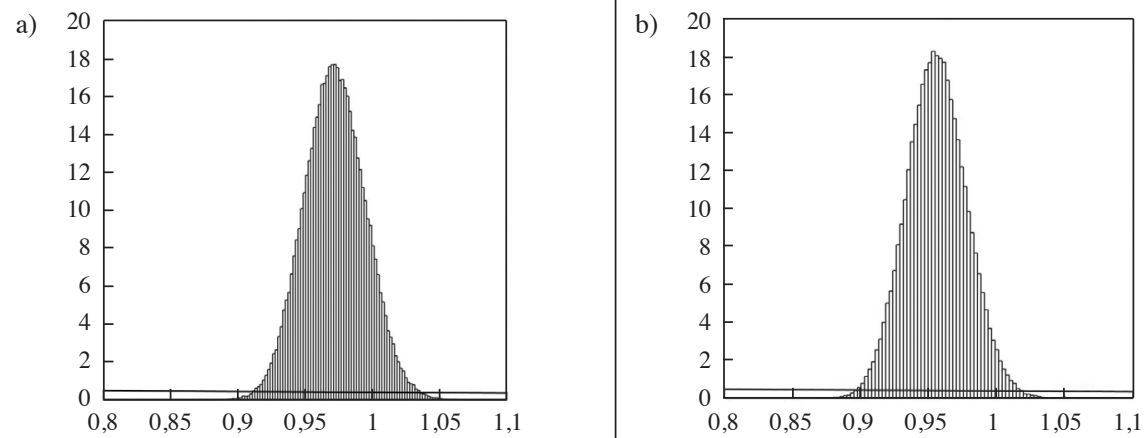

Rys. 4. Histogramy brzegowych rozkładów a posteriori parametru asymetrii w modelu dla: a) WIGBUD, b) WIGINF (linia ciągła - gęstość rozkładu a priori)

Źródło: opracowanie własne. 
Tabela 6. Wartości oczekiwane i odchylania standardowe (w nawiasach) a posteriori współczynnika tau Kendalla i zależności ogonowych

\begin{tabular}{|l|c|c|c|c|c|c|}
\hline \multirow{4}{*}{ Kopula } & \multicolumn{2}{|c|}{$\begin{array}{c}\text { Copula-AR(1)-GARCH(1,1) } \\
\text { z brzegowymi rozkładami }\end{array}$} & \multicolumn{2}{c|}{$\begin{array}{c}\text { Copula-AR(1)-GARCH(1,1) } \\
\text { z brzegowymi rozkładami } \\
\text { skośnymi } t \text {-Studenta }\end{array}$} \\
\cline { 2 - 8 } & \multicolumn{3}{|c|}{$t$-Studenta } & \multicolumn{2}{c|}{ tau } \\
Kendalla & $\lambda^{U}$ & $\lambda^{L}$ & $\begin{array}{c}\text { tau } \\
\text { Kendalla }\end{array}$ & $\lambda^{U}$ & $\lambda^{L}$ \\
\hline Franka & 0,3366 & 0 & 0 & 0,3364 & 0 & 0 \\
& $(0,0119)$ & $(0)$ & $(0)$ & $(0,0119)$ & $(0)$ & $(0)$ \\
\hline Claytona & 0,2706 & 0 & 0,3927 & 0,2828 & 0 & 0,4150 \\
& $(0,0106)$ & $(0)$ & $(0,0197)$ & $(0,0116)$ & $(0)$ & $(0,0209)$ \\
\hline Obrócona Claytona & 0,2706 & 0,3928 & 0 & 0,2505 & 0,3541 & 0 \\
& $(0,0106)$ & $(0,0197)$ & $(0)$ & $(0,0122)$ & $(0,0238)$ & $(0)$ \\
\hline Gumbela & 0,3125 & 0,3895 & 0 & 0,3149 & 0,3921 & 0 \\
& $(0,0121)$ & $(0,0135)$ & $(0)$ & $(0,0127)$ & $(0,0142)$ & $(0)$ \\
\hline Obrócona Gumbela & 0,3116 & 0 & 0,3884 & 0,3202 & 0 & 0,3981 \\
& $(0,0120)$ & $(0)$ & $(0,0134)$ & $(0,0123)$ & $(0)$ & $(0,0136)$ \\
\hline Claytona-Gumbela (BB1) & 0,3200 & 0,2322 & 0,2622 & 0,3220 & 0,2199 & 0,2838 \\
& $(0,0134)$ & $(0,0224)$ & $(0,0309)$ & $(0,0135)$ & $(0,0229)$ & $(0,0325)$ \\
\hline Joego-Claytona (BB7) & 0,3148 & 0,2844 & 0,3222 & 0,3157 & 0,2678 & 0,3390 \\
& $(0,0119)$ & $(0,0262)$ & $(0,0248)$ & $(0,0119)$ & $(0,0275)$ & $(0,0263)$ \\
\hline Symetryzowana & - & 0,2402 & 0,3561 & - & 0,2212 & 0,3712 \\
Joego-Claytona & & $(0,0291)$ & $(0,0223)$ & - & $(0,0304)$ & $(0,0236)$ \\
\hline Normalna & 0,320 & 0 & 0 & 0,3309 & 0 & 0 \\
& $(0,0111)$ & $(0)$ & $(0)$ & $(0,0112)$ & $(0)$ & $(0)$ \\
\hline -Studenta & 0,3288 & 0,1669 & 0,1669 & 0,3283 & 0,1621 & 0,1621 \\
& $(0,0123)$ & $(0,0401)$ & $(0,0401)$ & $(0,0123)$ & $(0,0404)$ & $(0,0404)$ \\
\hline
\end{tabular}

Źródło: opracowanie własne.

Charakterystyki rozkładów a posteriori współczynnika tau Kendalla (przedstawione w tabeli 6 i na rys. 5) wskazują na dodatnią zależność, tj. prawdopodobieństwo realizacji wektora losowego uporządkowanego zgodnie jest wyższe niż prawdopodobieństwo niezgodnego uporządkowania tego wektora. Szacowanie zależności ogonowych dało wartości niezerowe, co oznacza niezerowe prawdopodobieństwo równoczesnego przyjmowania wartości ekstremalnych. W modelu z kopulą Claytona-Gumbela na histogramach brzegowego rozkładu a posteriori zależności ogonowych (zob. rys. 6) widoczne jest nieznaczne przesunięcie rozkładu parametru dolnej zależności ogonowej w stosunku do rozkładu górnej zależności ogonowej. Wyższą wartość oczekiwaną a posteriori uzyskano dla dolnej zależności ogonowej. 


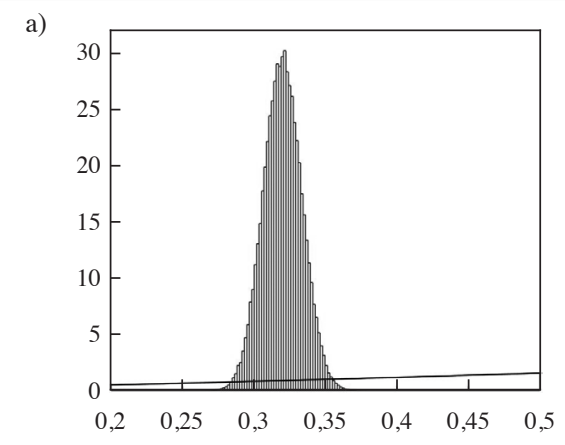

b)

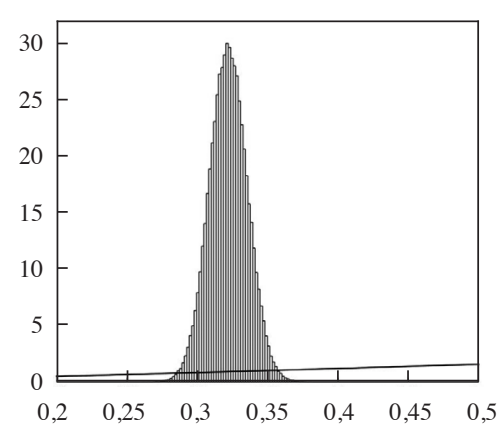

Rys. 5. Histogramy brzegowych rozkładów a posteriori współczynnika tau Kendalla w modelu z kopulą Claytona-Gumbela: a) dla modelu z brzegowymi rozkładami $t$-Studenta, b) dla modelu z brzegowymi rozkładami skośnymi $t$-Studenta (linia ciągła gęstość rozkładu a priori)

Źródło: opracowanie własne.

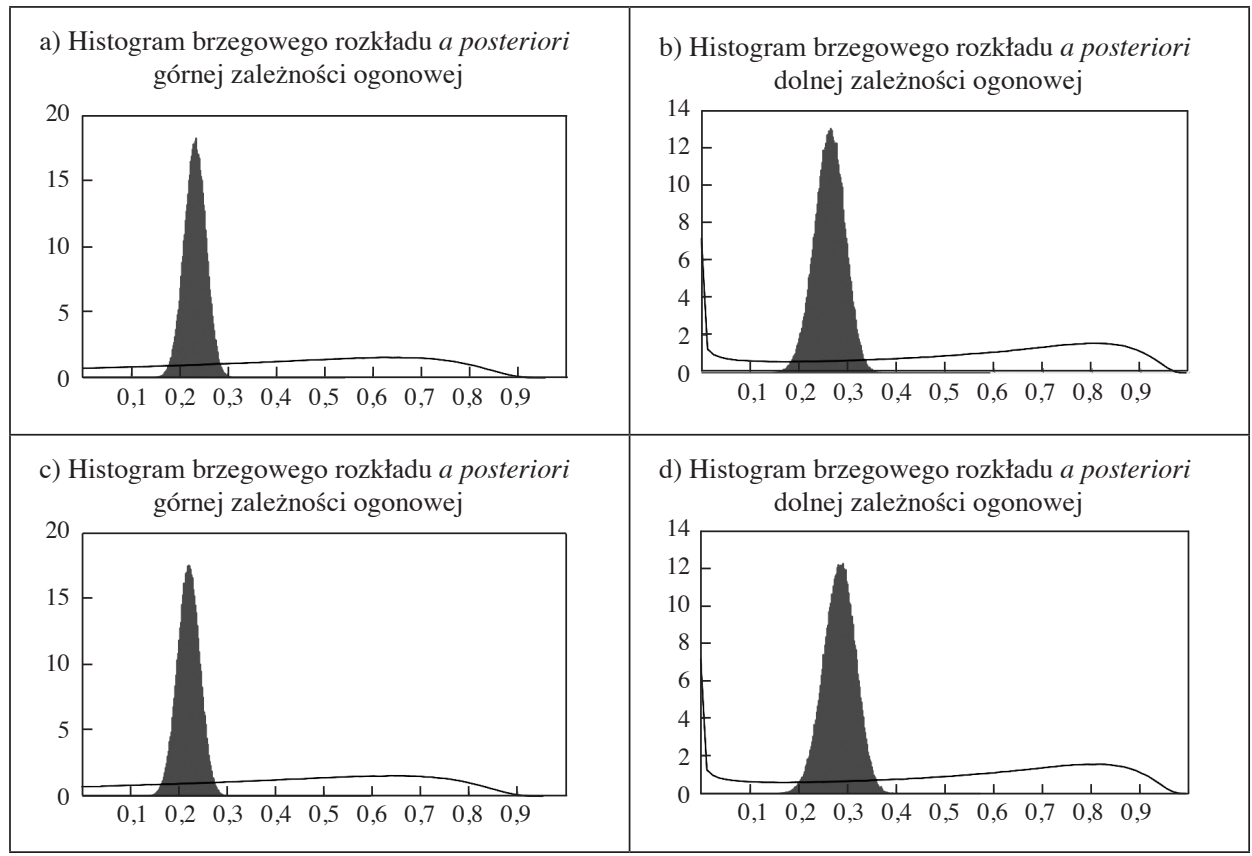

Rys. 6. Histogramy brzegowych rozkładów a posteriori zależności ogonowych w modelu z brzegowymi rozkładami $t$-Studenta (rys. a, b) i skośnymi $t$-Studenta (rys. c, d) (linia ciągła - gęstość rozkładu a priori)

Źródło: opracowanie własne. 
Tabela 7. Wyniki bayesowskiego łączenia wiedzy dla parametrów wspólnych modeli

\begin{tabular}{|c|c|c|c|c|c|c|}
\hline \multirow[t]{2}{*}{ Parametr } & \multicolumn{2}{|c|}{$\begin{array}{c}\text { Copula-AR(1)- } \\
\text {-GARCH }(1,1) \\
\text { z brzegowymi rozkładami } \\
t \text {-Studenta (11 modeli) }\end{array}$} & \multicolumn{2}{|c|}{$\begin{array}{c}\text { Copula-AR(1)- } \\
\text {-GARCH(1,1) } \\
\text { z brzegowymi rozkładami } \\
\text { skośnymi } \\
t \text {-Studenta (11 modeli) }\end{array}$} & \multicolumn{2}{|c|}{$\begin{array}{l}\text { Copula-AR(1)- } \\
\text {-GARCH(1,1) } \\
\text { (22 modele) }\end{array}$} \\
\hline & $E(\mid y)$ & $D(\mid y)$ & $E(\mid y)$ & $D(\mid y)$ & $E(\mid y)$ & $D(\mid y)$ \\
\hline$\varphi_{1,0}$ & 0,0284 & 0,0227 & 0,0648 & 0,0408 & 0,0285 & 0,0230 \\
\hline$\varphi_{1,1}$ & 0,0720 & 0,0177 & 0,0713 & 0,0177 & 0,0720 & 0,0177 \\
\hline$\alpha_{1,0}$ & 0,0233 & 0,0083 & 0,0242 & 0,0085 & 0,0233 & 0,0083 \\
\hline$\alpha_{1,1}$ & 0,0310 & 0,0070 & 0,0316 & 0,0070 & 0,0310 & 0,0070 \\
\hline$\beta_{1,1}$ & 0,9315 & 0,0158 & 0,9299 & 0,0160 & 0,9315 & 0,0157 \\
\hline$v_{1}$ & 5,1495 & 0,5174 & 5,1366 & 0,5132 & 5,1494 & 0,5194 \\
\hline$\varphi_{2,0}$ & 0,0486 & 0,0215 & 0,1092 & 0,0388 & 0,0488 & 0,0219 \\
\hline$\varphi_{2,1}$ & $-0,0428$ & 0,0181 & $-0,0451$ & 0,0182 & $-0,0428$ & 0,0181 \\
\hline$\alpha_{2,0}$ & 0,0455 & 0,0148 & 0,0455 & 0,0144 & 0,0455 & 0,0148 \\
\hline$\alpha_{2,1}$ & 0,0400 & 0,0086 & 0,0404 & 0,0086 & 0,0400 & 0,0086 \\
\hline$\beta_{2,1}$ & 0,8956 & 0,0240 & 0,8951 & 0,0235 & 0,8956 & 0,0239 \\
\hline$v_{2}$ & 5,2286 & 0,5457 & 5,3144 & 0,5667 & 5,2289 & 0,5482 \\
\hline$\gamma_{1}$ & - & - & 0,9721 & 0,0228 & - & - \\
\hline$\gamma_{2}$ & - & - & 0,9557 & 0,0223 & - & - \\
\hline $\begin{array}{c}\text { tau } \\
\text { Kendalla }\end{array}$ & 0,2500 & 0,1324 & 0,2508 & 0,1337 & 0,2500 & 0,1324 \\
\hline$\lambda^{L}$ & 0,2865 & 0,0494 & 0,3066 & 0,0485 & 0,2866 & 0,0491 \\
\hline$\lambda^{U}$ & 0,2373 & 0,0280 & 0,2325 & 0,0352 & 0,2373 & 0,0278 \\
\hline
\end{tabular}

Oznaczenia: $E(\mid y)$ - wartość oczekiwana, $D(\mid y)$ - odchylenie standardowe.

Źródło: opracowanie własne.

W tabeli 7 zamieszczono wyniki bayesowskiego łączenia wiedzy dla charakterystyk rozkładu a posteriori parametrów modelu. Zastosowanie tej techniki wpłynęło na obniżenie wartości współczynnika tau Kendalla oraz niewielkie zwiększenie wartości dolnej zależności ogonowej w porównaniu z modelem o najwyższym prawdopodobieństwie a posteriori.

\section{Podsumowanie}

W pracy podjęto próbę modelowania zmienności i zależności między finansowymi szeregami czasowymi z wykorzystaniem modeli Copula-AR(1)- 
-GARCH $(1,1)$ z brzegowymi warunkowymi rozkładami $t$-Studenta i skośnymi $t$-Studenta oraz jedenastoma typami kopul. Do tego celu wykorzystano bayesowskie wnioskowanie statystyczne, które jest podejściem formalnym i całościowym. Z uwagi na skomplikowane postaci gęstości rozkładów a posteriori charakterystyki tych 22 rozkładów oszacowano, stosując metodę Monte Carlo z funkcją ważności. Estymacja modeli została wykonana dla logarytmicznych, procentowych stóp zwrotu subindeksów WIG-Budownictwo i WIG-Informatyka. W wyniku formalnego bayesowskiego porównania 22 modeli wytypowano model Copula-AR(1)-GARCH(1,1) z kopulą Claytona-Gumbela i brzegowym, warunkowym, symetrycznym rozkładem $t$-Studenta jako model najlepiej opisujący stopy zwrotu subindeksów. W obu przypadkach analizowane modele Copula-GARCH z brzegowym warunkowym rozkładem skośnym $t$-Studenta uzyskały wartości prawdopodobieństw a posteriori dużo niższe od modeli z symetrycznym rozkładem $t$-Studenta. Uzyskane wyniki potwierdziły, że próbkowa ujemna wartość współczynnika skośności dla zwrotu subindeksów wynika z występowania obserwacji nietypowych w lewym ogonie rozkładu.

Ponadto w pracy zaprezentowano wyniki estymacji współczynnika tau Kendalla oraz zależności ogonowych dla 22 modeli, jak również estymację tych wielkości z zastosowaniem techniki bayesowskiego łączenia wiedzy. Uzyskane wyniki wskazują na częstsze występowanie uporządkowania zgodnego niż niezgodnego w analizowanej parze składowych wektora losowego (dodatnia wartość współczynnika tau Kendalla) oraz występowanie asymetrycznej struktury zależności w ogonach rozkładów (kopula Claytona-Gumbela).

\section{Literatura}

Bollerslev T. [1986], Generalized Autoregressive Conditional Heteroskedasticity, „Journal of Econometrics", vol. 31, nr 3, https://doi.org/10.1016/0304-4076(86)90063-1.

Czado C. [2010], Pair-Copula Construction of Multivariate Copulas [w:] Copula Theory and Its Application, P. Jaworski, F. Durante, W. Hardle, T. Rychlik (ed.), Lecture Notes in Statistics-Proceedings, Springer, Berlin.

Doman R. [2010], Modelling the Dependencies between the Returns on the Worsow Stock Indices Using Time Varying Copulas [w:] Financial Markets: Principles of Modelling, Forecasting and Decision-Making, W. Milo, P. Wdowiński, P. Szafrański (ed.), Find Econ Monograph Series: Advances in Financial Market Analysis, No. 8, Łódź University Press, Łódź.

Doman R. [2011], Zastosowania kopuli w modelowaniu dynamiki zależności na rynkach finansowych, Wydawnictwo Uniwersytetu Ekonomicznego w Poznaniu, Poznań.

Doman M., Doman R. [2014], Dynamika zależności na globalnym rynku finansowym, Difin, Warszawa.

Durante F., Sempi C. [2016], Principles of Copula Theory, CRS Press, Taylor and Francis Group LLC, Boca Raton. 
Fiszeder P. [2009], Modele klasy GARCH w empirycznych badaniach finansowych, Wydawnictwo Naukowe Uniwersytetu Mikołaja Kopernika, Toruń.

Geweke J. [1989], Bayesian Inference in Econometric Models Using Monte Carlo Integration, „Econometrica”, vol. 57, nr 6, https://doi.org/10.2307/1913710.

Huard D., Evin G., Favre A.C., [2006], Bayesian Copula Selection, „Computational Statistics and Data Analysis", vol. 51, nr 2, https://doi.org/10.1016/j.csda.2005.08.010.

Jaworski P. [2012], Wybrane zagadnienia modelowania zmienności na rynkach finansowych z wykorzystaniem kopuli i procesów GARCH, http://docplayer.pl/1206688-Wybranezagadnienia-modelowania-zmiennosci-na-rynkach-finansowych-z-wykorzystaniemkopuli-i-procesow-garch.html (data dostępu: 20.04.2017).

Joe H. [1993], Parametric Family of Multivariate Distribution with Given Margins, „Journal of Multivariate Analysis”, vol. 46, nr 2, https://doi.org/10.1006/jmva.1993.1061.

Jondeau E., Rockinger M. [2006], The Copula-GARCH Model of Conditional Dependencies: An International Stock Market Application, ,, Journal of International Money and Finance", vol. 25, nr 5, https://doi.org/10.1016/j.jimonfin.2006.04.007.

Kloek T., Dijk H.K. van [1978], Bayesian Estimates of Equation System Parameters. An Application of Integration by Monte Carlo, ,Econometrica”, vol. 46, nr 1, https:// doi.org/10.2307/1913641.

Mokrzycka J., Pajor A. [2016], Formalne porównanie modeli Copula-AR(1)-GRACH(1,1) dla subindeksów indeksu WIG, „Przegląd Statystyczny”, R. LXIII, z. 2.

Nelsen R.B. [1999], An Introduction to Copulas, Springer-Verlag, New York.

Osiewalski J. [2001], Ekonometria bayesowska w zastosowaniach, Wydawnictwo Akademii Ekonomicznej w Krakowie, Kraków.

Pajor A. [2003], Procesy zmienności stochastycznej SV w bayesowskiej analizie finansowych szeregów czasowych, Monografie: Prace Doktorskie, Nr 2, Wydawnictwo Akademii Ekonomicznej w Krakowie, Kraków.

Pajor A. [2017], Estimating the Marginal Likelihood Using the Arithmetic Mean Identity, „Bayesian Analysis”, vol. 12, nr 1, https://doi.org/10.1214/16-ba1001.

Patton A.J. [2001], Modelling Time Varying Exchange Rate Dependence Using the Conditional Copula, Discussion Paper2001-09 University of California, San Diego.

Patton A.J. [2006a], Estimation of Multivariate Models for Time Series of Possibly Different Lengths, ,Journal of Applied Econometrics”, vol. 21, nr 2, https://doi.org/10.1002/ jae.865.

Patton A.J. [2006b], Modelling Asymmetric Exchange Rate Dependence, „International Economic Review", vol. 47, nr 2, https://doi.org/10.1111/j.1468-2354.2006.00387.x.

Pipień M. [2006], Wnioskowanie bayesowskie w ekonometrii finansowej, Wydawnictwo Akademii Ekonomicznej w Krakowie, Kraków.

Rossi J.L., Ehlers R.S., Filho M.G.A. [2012], Copula-GARCH Model Selection: A Bayesian Approach, Technical Report 88, University of São Paulo, https:/www.semanticscholar.org/paper/Copula-GARCH-Model-Selection\%3A-A-Bayesian-ApproachRossi-Ehlersa/fc1d11dd1fbe3f46ae83f0ae87ae02a5cefb58fe.

Silva R., Lopes H.F. [2008], Copula Marginal Distributions and Model Selection: A Bayesian Note, ,Statistical Computing”, vol. 18, nr 3, https://doi.org/10.1007/s11222008-9058-y. 


\section{Comparision Bayesian Copula-AR(1)-GARCH(1,1) Models with Asymmetric Conditional Dystribution}

The main aim of the paper is to formally assess the relative explanatory power of competing bivariate Copula-AR-GARCH models with symmetric and skewed Student t distributions on the example of data from the The Warsaw Stock Exchange. The subject of comparison were 22 Copula-AR(1)-GARCH $(1,1)$ models, which differed in assumptions on the copula and the occurrence of skewness in marginal distributions. In the context of the models under consideration, Monte Carlo Important Sampling methods were used to estimate the characteristics of a posteriori distribution and the marginal density of the observation matrix. For analysing empirical data, a posteriori models turned out to be ones more likely to have symmetrical conditional $t$-Student distributions. For the logarithmic daily growth rates of the two sub-indicies of the stock index WIG, the highest a posteriori probability was obtained by the Clayton-Gumbel copula model. The use of the skewed Student's $t$-distribution did not improve the explanatory power of the Copula-GARCH models.

Keywords: copula, Copula-AR-GARCH model, Bayesian inference, Bayesian model comparison, Bayesian pooling approach, Monte Carlo Important Sampling. 